\title{
DISCIPLINA JURÍDICA DO IMPEACHMENT PRESIDENCIAL NO BRASIL
}

\section{LEGAL INSTITUTE OF THE PRESIDENTIAL IMPEACHMENT IN BRAZIL}

\author{
Ives Gandra da Silva Martins
}

\begin{abstract}
Professor Emérito das Universidades Mackenzie, UNIP, UNIFIEO, UNIFMU, do CIEE/O ESTADO DE SÃO PAULO, das Escolas de Comando e Estado-Maior do Exército - ECEME, Superior de Guerra - ESG e da Magistratura do Tribunal Regional Federal - $1^{\text {a }}$ Região; Professor Honorário das Universidades Austral (Argentina), San Martin de Porres (Peru) e Vasili Goldis (Romênia); Doutor Honoris Causa das Universidades de Craiova (Romênia) e da PUC-Paraná, e Catedrático da Universidade do Minho (Portugal); Presidente do Conselho Superior de Direito da FECOMERCIO - SP; Fundador e Presidente Honorário do Centro de Extensão Universitária CEU/Instituto Internacional de Ciências Sociais - IICS. E-mail: igm@gandramartins.adv.br
\end{abstract}

Convidado

Doi: $10.5585 / \mathrm{rdb} . v 14 \mathrm{i} 6.380$

RESUMO: Já faz algum tempo que o Brasil vem vivendo uma situação atípica desde a Proclamação da República e que se agrava a cada dia com a evolução das investigações da Operação Lava Jato acerca de esquemas de corrupção envolvendo políticos, empresas estatais (notadamente a Petrobrás) e agentes privados (principalmente empresas do setor de infraestrutura, isto é, empreiteiras). Os investigadores procuram comprovar a existência dolosa de certos crimes, envolvendo igualmente crimes eleitorais e atos de improbidade adminsitrativa. Referidos crimes, individual ou coletivamente perpetrados, sustentam e justificam a aplicação do instituto jurídico do impeachment presidencial. É defendida, no presente artigo, a existência de elementos jurídicos suficientes que o corroboram. Assim, aqui se objetiva discorrer sobre tal disciplina jurídica, muito em voga nos dias atuais, a partir de uma metodologia dedutiva e com base em relevante levantamento bibliográfico.

Palavras-chave: Regime jurídico; impeachment; presidencialismo; Brasil.

ABSTRACT: For some time, Brazil is living an atypical situation since the Proclamation of the Republic and that situation worsens every day with the progress of investigations of "Operação Lava Jato" focused on corruption schemes involving politicians, state-owned companies (notably Petrobras) and private agents (especially companies in the infrastructure sector, i.e., engineering companies). Investigators seek to prove the intentional existence of certain crimes, also involving electoral crimes and acts of administrative misconduct. Such crimes, individually or collectively perpetrated, sustain and justify the use of the legal institute of the presidential impeachment. It held, in this article, the existence of sufficient legal elements that corroborate the use of such institute. Therefore, the main goal of this article is to discuss such legal discipline, very much in vogue today, from a deductive methodological point of view and based on relevant literature.

Keywords: Legal institute; impeachment; presidentialism; Brazil

SUMÁRIO: Introdução; Das missões propositiva e interpretativa; Sobre o parlamentarismo; Do elemento subjetivo (dolo e culpa); Da responsabilidade objetiva do estado e subjetiva do agente público; Da ação de regresso; Da jurisprudência; Dos fatos concretos; Conclusão; Bibliografia. 


\section{INTRODUÇÃO}

A cada dia que passa, a situação política do país se agrava e o envolvimento do Governo nos escândalos deflagrados, de modo especial, pela Operação Lava Jato se torna mais patente. Tanto as diversas delações premiadas quanto as investigações da Polícia Federal tendem a comprovar a existência dolosa de crimes eleitorais e de atos de improbidade administrativa, razões mais que suficientes para justificar o impeachment presidencial. Tudo isso, sem considerar que, ao nomear o ex-presidente Luiz Inácio da Silva (então suspeito de corrupção com pedido de prisão preventiva) como Ministro da Casa Civil (em março de 2016), a Presidente ofendeu pelo menos quatro dos cinco princípios fundamentais da Administração Pública: moralidade, impessoalidade, legalidade e eficiência (artigo 37 da CF/88).

Conforme ficará demonstrado no decorrer deste estudo, o impeachment é instrumento democrático e constitucional (artigos 85 e 86 da CF/88), a ser analisado mais política do que juridicamente pelo Congresso Nacional.

Entretanto, sob o aspecto exclusivamente jurídico, independentemente das apurações que estão sendo realizadas pela Polícia Federal e Ministério Público (hipótese de dolo), entendo que há elementos jurídicos para que seja admitido o impeachment da atual presidente da República, Dilma Rousseff, perante a Câmara dos Deputados e Senado Federal, por hipótese de culpa grave. É, pois, em razão desta figura jurídica que me debruçarei sobre o tema.

\section{DAS MISSÕES PROPOSITIVA E INTERPRETATIVA}

Gostaria de esclarecer, inicialmente, que como advogado e professor de Direito, tenho buscado, no curso de meus 59 anos de atuação na área jurídica e 56 anos de magistério universitário, ater-me a duas linhas de atuação, quais sejam:

(1) propositiva e de lege ferenda, participando da elaboração de inúmeros projetos de emenda constitucional, leis complementares, resoluções de congresso, além de ter sido ouvido inclusive em audiências públicas, seja na Constituinte, seja no processo legislativo de muitas das leis em vigor no Brasil;

(2) como intérprete do direito posto, procurando interpretá-lo rigorosamente à luz do instrumental hermenêutico, preocupado em afastar-me da crítica de Ferrara $^{1}$, ao condenar os intérpretes "ideológicos", que, muitas vezes, colocam na lei o que na lei não está para atender às suas preferências pessoais ou da lei retiram o que nela está, por não concordarem com o disposto no texto.

O intérprete do direito deve utilizar-se de todas as formas e métodos possíveis para chegar ao conteúdo ôntico das normas, mas deve respeitar o direito positivo, independentemente de suas preferências ou antipatias.

Nestes 59 anos de atuação como operador do direito, tenho sempre distinguido essas duas missões próprias do advogado ou do jurista, ou seja, a propositiva, em que tudo deve fazer para melhorar o que lhe parece possível no sistema e a interpretativa da ordem jurídica como foi elaborada, ao aplicar o direito positivo.

Como cidadão, senti-me, no curso de minha vida, no direito de criticar governos de qualquer ideologia, quando entendi não estarem cumprindo o seu dever para com a pátria e à sociedade. À evidência, tal crítica decorreu sempre do meu repúdio a desmandos, desvios,

\footnotetext{
${ }^{1}$ Hamilton Dias de Souza, em estudo que publicou em livro conjunto comigo, Henry Tilbery e José Carlos Graça Wagner, sobre este risco assim se manifestou: "deve-se lembrar a lição de Francesco Ferrara, segundo a qual o excessivo apego à letra da lei é pernicioso, mas, ainda mais grave é o perigo de que o intérprete force a exegese, encaixando no texto aquilo que gostaria que lá estivesse ou suprimindo o que contrariasse suas preferências" (Direito Tributário 2, José Bushatsky editor, São Paulo, 1972, p. 32). Francesco Ferrara, "Interpretação e aplicação das leis", $2^{a}$. edição, Ed. Coimbra, p. 129.
}

Revista de Direito Brasileira | São Paulo, SP | v. 14 | n. 6 | p. 231 - 251 | maio/ago. 2016 
principalmente quando a corrupção ou concussão estavam na essência de tais comportamentos públicos. Como cidadão, portanto, não me sinto prisioneiro do direito positivo, do qual sou, como advogado. Embora respeite o direito posto, como cidadão, sou livre para expor minhas opiniões e críticas. É o que tenho feito em livros, palestras e pela imprensa escrita, radiofônica e televisiva ${ }^{2}$. Quero deixar claro, pois, uma vez mais, que a análise que farei, neste estudo, não é a do cidadão, exercendo a cidadania - no meu caso, com modéstia e limitações -, mas a do jurista ${ }^{3}$, mantendo-me exclusivamente adstrito ao texto constitucional, de resto, por ter exercido a cátedra de Direito Constitucional até 1992, na Faculdade de Direito da Universidade Mackenzie, e ter comentado a lei suprema, em mais de 12.000 páginas, 15 volumes, pela Editora Saraiva, com o saudoso professor Celso Bastos.

Quando do processo contra o Presidente Collor, elaborei dois pareceres sobre a matéria, um, a pedido do deputado Hélio Bicudo, mostrando que a matéria deveria ser examinada pelo Congresso, e outro, para o Presidente Collor, entendendo - contra a opinião de meu confrade nas Academias Paulista de Letras e Letras Jurídicas, Miguel Reale Jr. - que, tanto para o juízo de admissibilidade na Câmara dos Deputados, como para o julgamento do próprio mérito, haveria necessidade de 2/3 da Casa Legislativa a favor da medida. Miguel Reale Jr. defendia a tese de

2 Nas minhas duas trilogias ("O Poder", "A nova classe ociosa" e "O Direito do Estado e o Estado de Direito" e "Uma visão do mundo contemporâneo", "A era das contradições" e "A queda dos mitos econômicos" escrevi como cidadão, que se sente na obrigação de trazer sua pessoal reflexão sobre o exercício do poder.

3 Para que fique claro que o presente estudo é apenas jurídico, sem qualquer conotação política, transcrevo o Decálogo do Advogado, que escrevi para meus alunos da Universidade Mackenzie, na década de 80:

“1. O Direito é a mais universal das aspirações humanas, pois sem ele não há organização social. O advogado é seu primeiro intérprete. Se não considerares a tua como a mais nobre profissão sobre a terra, abandona-a porque não és advogado.

2. O direito abstrato apenas ganha vida quando praticado. E os momentos mais dramáticos de sua realização ocorrem no aconselhamento às dúvidas, que suscita, ou no litígio dos problemas, que provoca. $\mathrm{O}$ advogado é o deflagrador das soluções. Sê conciliador, sem transigência de princípios, e batalhador, sem tréguas, nem leviandade. Qualquer questão encerra-se apenas quando transitada em julgado e, até que isto ocorra, o constituinte espera de seu procurador dedicação sem limites e fronteiras.

3. Nenhum país é livre sem advogados livres. Considera tua liberdade de opinião e a independência de julgamento os maiores valores do exercício profissional, para que não te submetas à força dos poderosos e do poder ou desprezes os fracos e insuficientes. O advogado deve ter o espírito do legendário El Cid, capaz de humilhar reis e dar de beber a leprosos.

4. Sem o Poder Judiciário não há Justiça. Respeita teus julgadores como desejas que teus julgadores te respeitem. Só assim, em ambiente nobre e altaneiro, as disputas judiciais revelam, em seu instante conflitual, a grandeza do Direito. 5. Considera sempre teu colega adversário imbuído dos mesmos ideais de que te revestes. E trata-o com a dignidade que a profissão que exerces merece ser tratada.

6. O advogado não recebe salários, mas honorários, pois que os primeiros causídicos, que viveram exclusivamente da profissão, eram de tal forma considerados, que o pagamento de seus serviços representava honra admirável. Sê justo na determinação do valor de teus serviços, justiça que poderá levar-te a nada pedires, se legítima a causa e sem recursos o lesado. É, todavia, teu direito receberes a justa paga por teu trabalho.

7. Quando os governos violentam o Direito, não tenhas receio de denunciá-los, mesmo que perseguições decorram de tua postura e os pusilânimes te critiquem pela acusação. A história da humanidade lembra-se apenas dos corajosos que não tiveram medo de enfrentar os mais fortes, se justa a causa, esquecendo ou estigmatizando os covardes e os carreiristas.

8. Não percas a esperança quando o arbítrio prevalece. Sua vitória é temporária. Enquanto, fores advogado e lutares para recompor o Direito e a Justiça, cumprirás teu papel e a posteridade será grata à legião de pequenos e grandes heróis, que não cederam às tentações do desânimo.

9. O ideal da Justiça é a própria razão de ser do Direito. Não há direito formal sem Justiça, mas apenas corrupção do Direito. Há direitos fundamentais inatos ao ser humano que não podem ser desrespeitados sem que sofra toda a sociedade. Que o ideal de Justiça seja a bússola permanente de tua ação, advogado. Por isto estuda sempre, todos os dias, a fim de que possas distinguir o que é justo do que apenas aparenta ser justo.

10. Tua paixão pela advocacia deve ser tanta que nunca admitas deixar de advogar. E se o fizeres, temporariamente, continua a aspirar o retorno à profissão. Só assim poderás, dizer, à hora da morte: "Cumpri minha tarefa na vida. Restei fiel à minha vocação. Fui advogado"'”. 
que, só para o julgamento no Senado os 2/3 seriam necessários, visto que para o juízo de admissibilidade bastaria maioria absoluta ${ }^{4}$.

Tanto num caso, como no outro, minha tese prevaleceu ${ }^{5}$.

Apesar de não ter conseguido $1 / 3$, pelo menos, dos parlamentares nas duas Casas e ter sofrido o impeachment por decisão política, foi o Presidente Collor absolvido pelo Supremo Tribunal Federal, que não encontrou nexo causal para justificar sua condenação, entre os fatos alegados e eventuais benefícios auferidos no exercício do governo ${ }^{6}$.

É que o julgamento da Suprema Corte difere do julgamento do Congresso Nacional, aquele apenas voltado para os aspectos jurídicos do impeachment e este para os aspectos exclusivamente políticos e de governabilidade ${ }^{7}$.

\footnotetext{
${ }^{4}$ Os dois pareceres e outros estudos foram publicados pela Editora Cejup em 1992, sob o título "O "impeachment" na Constituição de 1988".

${ }^{5}$ No parecer, ao Deputado do PT, Hélio Bicudo, lembrei que a "omissão" geraria também crime de responsabilidade em face da lei, transcrevendo parte do texto:

O exame da dicção dos diversos dispositivos da lei 8429/92 demonstra que a abrangência foi de tal ordem que nada restou para os crimes comuns.

Reza, por exemplo, o artigo 11 inciso I que: "Constitui ato de improbidade administrativa que atenta contra os princípios da administração pública qualquer ação ou omissão que viole os deveres de honestidade, imparcialidade, legalidade e lealdade às instituições, e notadamente:

I. praticar ato visando fim proibido em lei ou regulamento ou diverso daquele previsto, na regra de competência" (grifos meus).

Assim sendo, não há crime comum cujo fato delituoso não seja proibido em lei, razão pela qual a lei n $^{\circ} 8429 / 92$, no que diz respeito à responsabilização do Presidente da República, teria "revogado" as hipóteses de "crime comum" mencionadas no artigo 86 da Constituição Federal.

De lembrar-se que a Constituição Federal não só cuida dos crimes comuns praticados pelo Presidente, no "caput" do artigo 86, como outorga ao STF a competência para julgá-los (art. 102 inciso I). Estão os dispositivos assim redigidos:“Art. 86. Admitida a acusação contra o Presidente da República, por 2/3 da Câmara dos Deputados, será ele submetido a julgamento perante o STF, nas infrações penais comuns, ou perante o Senado Federal, nos crimes de responsabilidade";

"Art. 102. Compete ao STF, precipuamente, a guarda da Constituição, cabendo-lhe:

I - processar e julgar, originariamente:
}

b) nas infrações penais comuns, o Presidente da República, o vice-presidente, os membros do Congresso Nacional, seus próprios ministros e o procurador-geral da República".

Ora, se todos os crimes comuns elencados na lei 8429/92 exteriorizam a improbidade administrativa, todos esses crimes, teoricamente, seriam crimes de responsabilidade e não crimes comuns, com o que a lei $\mathrm{n}^{\circ}$ 8429/92 teria "revogado" o art. 86, o art. 102 inciso I e inclusive o $\S 4^{\circ}$ do mesmo dispositivo. $\mathrm{O} \S 4^{\circ}$ do art. 86, em verdade, apenas se refere aos crimes de responsabilidade, visto que não pode o Presidente ser acionado por tal espécie de crime fora de suas funções, nem pode ser responsabilizado, perante o Senado, por crimes comuns, de possível prática somente fora de suas funções.

Ora, ao usar a expressão responsabilizacão parece-me ter o constituinte cuidado dos crimes de responsabilidade e não dos crimes comuns, pois estes somente podem ocorrer em atos estranhos ao exercício de suas funções" ("O impeachment na Constituição de 1988”, Ed. Cejup, Belém do Pará, 1992, p. 42 a 45).

6 AP 307-DF, Relator Ilmar Galvão, Autor: Ministério Público Federal, $1^{\circ}$ réu: Fernando Affonso Collor de Mello, Julgamento: 13/12/1994, $2^{\text {a }}$. Turma.

7 Paulo Brossard lembra que:

"No sistema parlamentar, porque não governa, o Presidente é politicamente irresponsável. O governo cabe ao ministério, gabinete ou conselho de ministros, órgão colegiado, com unidade política, homogeneidade, solidariedade coletiva e co-responsabilidade na política do governo, guiado pelo Primeiro Ministro, Chefe de Gabinete, Presidente do Conselho de Ministros, Premier ou Chanceler, que é o chefe do governo. Politicamente responsável é o gabinete, porque o gabinete governa. O Presidente, que preside e não governa, não tem responsabilidade política; só é responsável em casos de alta traição.

28. Porém, ainda quando, nos países que adotam o sistema parlamentar, a locução "responsabilidade política" tenha outro sentido, que contrasta em geral com a apurada mediante o "impeachment", ou em processo a este semelhante, no Brasil, como nos Estados Unidos e na Argentina, por exemplo, onde vigora o sistema presidencial, pelo referido processo, com fases e formas que o assemelham ao processo judicial, não se apura senão a responsabilidade política,

Revista de Direito Brasileira | São Paulo, SP | v. 14 | n. 6 | p. 231 - 251 | maio/ago. 2016 
Assim, quaisquer que sejam os argumentos jurídicos a justificar o impeachment, a decisão parlamentar será sempre, indiscutivelmente, política, lembrando-se que, mesmo nos Estados Unidos, o instituto jamais foi aplicado.

Neste particular, como afirmou o eminente mestre Paulo Brossard, também parlamentarista - quando eu presidia o Partido Libertador em São Paulo, ele era secretário geral do PL no Rio Grande do Sul -, sendo seu livro sobre o impeachment obra clássica e de obrigatória leitura para quem se debruçar sobre o tema, o julgamento é sempre político, como, de resto, o é, nos sistemas parlamentares, os votos de confiança ou desconfiança a um gabinete, por parte do Parlamento, para manter ou afastar um governo. Por isto, critica o instrumento político, de rara utilização, ao dizer:

A experiência revela que o "impeachment" é inepto para realizar os fins que lhe foram assinados pela Constituição. Ele não assegura, de maneira efetiva, a responsabilidade política do Presidente da República.

Este registro é de indisfarçável gravidade, pois a Constituição apregoa, logo em seu preâmbulo, o propósito de "organizar um regime democrático". E democracia supõe a responsabilidade dos que dirigem a coisa pública.

Depois, tanto mais grave e chocante é esta conclusão quando se tenha presente a advertência que, já em 1826, fazia Bernardo Pereira de Vasconcellos, recém abertas as portas do Parlamento Brasileiro: "sem responsabilidade efetiva não há Constituição senão em papel ${ }^{8}$.

Assim sendo, os argumentos, rigorosa e exclusivamente jurídicos que apresentarei neste estudo, se, um dia, vierem a ser examinados por um Tribunal Político (Congresso Nacional), poderão merecer outras considerações que transcendam a minha obrigação de apenas considerar os aspectos exclusivamente jurídicos, de acordo com minha exegese do texto constitucional, que, como sempre coloco, em meus pareceres, pode comportar melhor juízo.

\section{SOBRE O PARLAMENTARISMO}

Gostaria de, inicialmente, no que diz respeito aos sistemas de governo, tecer alguns esclarecimentos.

Sempre fui parlamentarista. Manifestei essa minha preferência nas diversas conversas com os constituintes; no livro "Roteiro para uma Constituição", que redigi a pedido de 66 constituintes, editado pela Forense em 1986; nos artigos publicados em obras sobre o parlamentarismo (Mário Henrique Simonsen e eu defendemos, por ocasião do plebiscito, esta forma de governo ${ }^{9}$ ); no livro que coordenei com Celso Bastos e editado também pela Forense em 1987 e $1993^{10}$; no livro escrito para o plebiscito de 1993 (embora não sendo monarquista), intitulado "O que é Parlamentarismo Monárquico?"11 e no artigo publicado no livro ${ }^{12}$ do Tribunal

através da destituição da autoridade e sua eventual desqualificação para o exercício de outro cargo" ("O impeachment", obra cit. p. 36/37).

${ }^{8}$ Paulo Brossard, "O impeachment", ob. cit. p. 204.

9 O livro está intitulado "Plebiscito: como votarei?" (José Olympio Editora, Rio de Janeiro, 1993), tendo dele participado os seguintes autores: Antonio Ermírio de Moraes, Antonio Fernando de Bulhões Carvalho, Benito Gama, Carlos Alberto Sardenberg, Edmar Bacha, Ives Gandra Martins, Marco Maciel, Mário Henrique Simonsen, Ozires Silva e Paulo Rabello de Castro.

10 O livro intitulado "Parlamentarismo ou Presidencialismo?", de coordenação minha e de Celso Bastos, foi editado pela Academia Internacional de Direito e Economia e Editora Forense, Rio de Janeiro,. 1993, $2^{\mathrm{a}}$. edição, tendo como autores: Celso Bastos, Eduardo Muylaert Antunes, Imaculada Milani, Ives Gandra Martins, Maria Garcia, Marcelo de Oliveira Fausto Figueiredo Santos.

11 “O que é Parlamentarismo Monárquico?", Ed. Brasiliense, São Paulo, 1993.

Revista de Direito Brasileira | São Paulo, SP | v. 14 | n. 6 | p. 231 - 251 | maio/ago. 2016 
Regional Eleitoral de São Paulo, por comemoração de seus 80 anos, sobre os três anos em que exerci a presidência do único partido parlamentarista do Brasil, antes do Ato Institucional $\mathrm{n}^{\mathbf{o}} 2$, em São Paulo. Sempre defendi esta forma de governo, mais moderna e adotada por todos os países desenvolvidos, menos os Estados Unidos.

Lijphart, ao analisar as 20 democracias mais estáveis do mundo, após a $2^{\text {a }}$ guerra mundial, encontrou apenas um país presidencialista e dezenove parlamentaristas ${ }^{13}$.

A própria Constituição brasileira foi projetada, nas diversas Comissões (8), Subcomissões (24) e na Comissão de Sistematização, para hospedar o sistema parlamentar, o que só veio a ser modificado no plenário, após a formação do grupo denominado "Centrão", sob a liderança do Deputado Roberto Cardoso Alves.

Alguns dos institutos próprios do sistema parlamentar - medida provisória, por exemplo, copiado do texto constitucional italiano - não foram retirados do texto constitucional, quando, na undécima hora, voltou-se ao sistema presidencial, com diversas versões históricas sobre o motivo da mudança, que não são objeto de reflexão neste estudo. É de se lembrar que os constituintes repudiavam o que denominavam de instrumento da ditadura, ou seja, o Decreto-lei, que foi retirado do texto. Mas, introduziram a medida provisória, concebida para o sistema parlamentar, como instrumento de governança, sujeita sempre, à sua aprovação final pelo Parlamento. Sua rejeição poderia gerar até voto de desconfiança ao Gabinete ${ }^{14}$.

A característica maior do parlamentarismo é ser o governo da "responsabilidade a prazo incerto", pois, uma vez escolhido pelo Parlamento - que é a Casa de toda a nação, onde estão representados situação e oposição - um irresponsável para chefe de governo, por meio de votos de desconfiança, pode ser derrubado, sem traumas políticos para a nação. Margareth Thatcher ficou no governo inglês por onze anos - mais do que pode ficar um presidente brasileiro ou americano -, sendo derrubada, quando pretendeu elevar a tributação sobre determinados bens. No parlamentarismo, há mecanismos naturais de alternância do poder, sempre que o governo seja incompetente, corrupto ou inexperiente ${ }^{15}$.

12 "Minha presidência do Diretório Metropolitano do Partido Libertador", texto publicado no livro "Paulistânia Eleitoral - ensaios, memórias, imagens”, 80 anos do TRE-SP, editado pela Imprensa Oficial do Governo do Estado de São Paulo, 2011, organizador José D’Amico Bauab, colaboradores: Antonio Aguillar, Rodrigo Archangelo, Paulo Bomfim, Marília Gabriela Buonavita, Maria Celina D’Araújo, Célio Debes, Carlos Alberto Ungaretti Dias, Rubem Azevedo Lima, Ives Gandra da Silva Martins, Geraldina Marx, José Álvaro Moisés, Bryan Pitts, Maria Ligia Coelho Prado, Ubirajara de Farias Prestes Filho, Jade Almeida Prometti, Renato Janine Ribeiro e Marcelo Tápia.

13 "Democracies", Ed. Yale, 1984.

14 Leon Fredja Szklarowsky escreve: "As Medidas Provisórias foram feitas de encomenda, para o regime parlamentarista que não vingou (a figuração do Estado Brasileiro está toda modelada na estrutura parlamentarista. restando um sistema quase-híbrido), inspiradas no modelo constitucional italiano (parlamentarista). "Verbis": 'O governo não pode, sem delegação das Câmaras, promulgar decretos que tenham valor de lei ordinária’.

'Quando, em casos extraordinários de necessidade e de urgência, o governo adota, sob a sua responsabilidade, medidas provisórias, com força de lei, deve apresentá-las no mesmo dia para a conversão às Câmaras que, mesmo dissolvidas, são especialmente convocadas a se reunirem no prazo de cinco dias.'

Essa ordem constitucional dispõe também sobre a perda de eficácia, desde o início, se não se converterem em lei, no prazo de sessenta dias, a partir de sua publicação e faculta (a Lei brasileira determina) ainda às Câmaras regulamentar por lei as relações jurídicas oriundas desses decretos não convertidos.

Os textos brasileiro e italiano identificam-se, extraordinariamente.

Sara Ramos de Figueiredo, apoiada na doutrina italiana, fala na existência de 'estado de necessidade legislativa', ou 'estado de necessidade' para justificar a medida provisória, ou, na expressão de Giuseppe Viesti, ao comentar o art. 77, 'a adoção dos decretos-leis está condicionada à existência de circunstâncias intrinsecamente excepcionais, de tal forma que, se não fossem devidamente enfrentadas, decorreria um prejuízo concreto e certo para os interesses fundamentais cuja tutela cabe ao Estado" (Medidas provisórias, Revista dos Tribunais, 1991, p. 29-30).

${ }^{15}$ Celso Bastos lembra a origem do sistema:

"O século XVIII registrou conquistas muito importantes. Os dois primeiros Reis Stuarts sofreram violenta reação do Parlamento quando tentaram regredir para o absolutismo monárquico. Logo em 1628, foi arrancada do rei a petição de direitos, pela qual se confirmavam direitos e liberdades anteriormente

Revista de Direito Brasileira | São Paulo, SP | v. 14 | n. 6 | p. 231 - 251 | maio/ago. 2016 
No presidencialismo, não. É o sistema da "irresponsabilidade a prazo certo", pois, eleito um irresponsável, ou se o mantém até o final no poder ou deve-se recorrer ao traumático processo do impeachment.

Quando da preparação dos trabalhos constituintes do Paraguai fui convidado, com constitucionalistas de toda a América, a expor minhas idéias, em Congresso organizado pelo Ministério da Justiça. Tive, então, oportunidade de mostrar não haver incompatibilidade entre adotar mecanismos semelhantes ao "voto de confiança" dos sistemas parlamentares, no regime presidencialista $^{16}$. Outros constitucionalistas devem ter defendido ideias semelhantes - não assisti a todas as palestras -, pois o artigo 225 da Constituição paraguaia hospedou essa inteligência:

\section{“Artículo 225 - DEL PROCEDIMIENTO}

El Presidente de la República, el Vicepresidente, los ministros del Poder Ejecutivo, los ministros de la Corte Suprema de Justicia, el Fiscal General del Estado, el Defensor del Pueblo, el Contralor General de la República, el Subcontralor y los integrantes del Tribunal Superior de Justicia Electoral, sólo podrán ser sometidos a juicio político por mal desempeño de sus funciones, por delitos cometidos en el ejercicio de sus cargos o por delitos comunes.

La acusación será formulada por la Cámara de Diputados, por mayoría de dos tercios. Corresponderá a la Cámara de Senadores, por mayoría absoluta de dos tercios, juzgar en juicio público a los acusados por la Cámara de Diputados y, en caso, declararlos culpables, al sólo efecto de separarlos de sus cargos, en los casos de supuesta comisión de delitos, se pasarán los antecedentes a la justicia ordinaria" (grifos meus).

$\mathrm{O}$ artigo concilia, portanto, o impeachment com o voto de confiança parlamentar, pois, por "má performance" administrativa, pode um presidente eleito ser simplesmente afastado do governo, algo que, realmente, ocorreu com o Presidente Lugo, em processo rigorosamente constitucional.

adquiridos.

Sucederam-se os conflitos entre o rei e o Parlamento que conduziram à dissolução deste último durante onze anos. Após esse período convocou-se novo Parlamento, sobreveio a Guerra Civil, decapitou-se o rei e implantou-se a República em 1649, que no fundo encerrava uma ditadura parlamentar contra a qual se insurgiu uma revolução liderada por Cromwell, que estabeleceu um governo autoritário e pessoal. Com a sua morte a monarquia foi restaurada. O que é certo, contudo, é que nada obstante ter o Parlamento sofrido nesta época grandes dificuldades, fundamentalmente foram mantidas as prerrogativas obtidas no seu período áureo (ditadura parlamentar).

O Reinado dos Stuarts terminava com a Revolução Gloriosa de 1688 que, sem derramamento de sangue, destronou o rei e colocou um outro, de uma nova dinastia, no seu lugar (Guilherme de Orange). Abriu-se, então, um período de grandes conquistas parlamentares. Os próprios fatos históricos estavam a demonstrar que a nova monarquia era implantada por decisão do Parlamento. Na ocasião, inclusive, extraiu-se nova concessão régia, denominada Bill of Rights, que encerrou a trasladação, para o Parlamento, de uma série de prerrogativas que até então eram exercidas pelo rei. Vê-se, assim, como foi-se processando, na Inglaterra, uma gradual deslocação dos privilégios monárquicos em favor do Parlamento" ("Parlamentarismo ou Presidencialismo?", Série Realidade Brasileira, volume II, Ed. Forense/Academia Internacional de Direito e Economia, Rio de Janeiro, 1987, p. 4/5).

${ }^{16}$ Quando presidia a Fundação Alexandre de Gusmão, o Embaixador Jerônimo Moscardo promoveu o $1^{\circ}$ Encontro de Juristas da América e do Caribe, ocasião em que publicou todos os textos constitucionais dos países latinoamericanos e do Caribe (5 volumes) e um volume de estudos a respeito do constitucionalismo desta parte do continente. O livro "I Encontro de juristas da América Latina e do Caribe - volume IV - Reflexões", Ed. Fundação Alexandre de Gusmão, Brasília, 2010, teve a colaboração dos seguintes autores: Antonio Paulo Cachapuz de Medeiros, Arturo Hoyos, Hernán Salgado Pesantes, Hugo Esteban Estigarribia Gutiérrez, Ivan Escobar Fornos, Ives Gandra da Silva Martins, Jorge Antonio Giammattei Avilés, José Antonio Rivera S., Luiz Dilermando de Castello Cruz, Nestor Pedro Sagués, Rubén Hernández Valle, Suzie d'Auvergne, Walter Antillon e João Grandino Rodas. 
A ideia do voto de confiança é permitir alteração de rumos de um governo que, embora eleito pelos representantes do povo, pode não estar cumprindo o que o povo dele esperaria ${ }^{17}$.

$\mathrm{Na}$ Comissão de Reforma Política da OAB-SP, que presido, aprovamos, nos anteprojetos que redigimos, um sistema de recall, inclusive para cargos legislativos ${ }^{18}$. Se o Brasil tivesse adotado o projeto inicialmente discutido nas diversas Comissões na Constituinte, teríamos, indiscutivelmente, instrumento mais moderno para alternância do poder, desde que detectados fatos graves de gestão, dolosos ou culposos.

Passo, agora, a examinar os dispositivos do texto constitucional, que são essenciais para a compreensão do presente estudo.

\section{DO ELEMENTO SUBJETIVO (DOLO E CULPA)}

$\mathrm{O}$ artigo 85, inciso V da Constituição Federal possui a seguinte dicção:

Art. 85. São crimes de responsabilidade os atos do Presidente da República que atentem contra a Constituição Federal e, especialmente, contra:

(...) V - a probidade na administração; (...)

Em relação aos crimes contra a probidade da administração, não havendo explicitação sobre se, para sua caracterização, os atos hão de ser dolosos ou culposos, impõe-se considerar tanto uns, quanto outros.

Probo é o cidadão íntegro, que, com competência e zelo, exerce suas atividades, sendo o vocábulo sinônimo de honesto. O constituinte, lastreado no direito anterior, considerou que o crime de responsabilidade contra a "probidade em administração" justifica a abertura de um processo de impeachment, com eventual perda de mandato ${ }^{19}$.

\footnotetext{
${ }^{17}$ Maria Garcia esclarece:
}

"O parlamentarismo em sua conotação moderna, conforme coloca Paulo Bonavides, apóia-se sobre uma base de requisitos mínimos e essenciais,238cuja presença, compõe a natureza do sistema. Enumerados por Klaus Stern, são estes os requisitos: "a) a presença, em exercício, do governo, enquanto a maioria do Parlamento não dispuser o contrário, retirando-lhe o apoio; b) a repartição, entre o governo e o Parlamento, da função, de estabelecer as decisões políticas fundamentais; e c) a posse recíproca de meios de controle por parte do governo e do Parlamento, de modo que o primeiro, sendo responsável perante o segundo, possa ser destituído de suas funções mediante um voto de desconfiança da maioria parlamentar.

No mais, ressalta, "o parlamentarismo oferece contextura flexível, admite variantes e configura distintos modelos, consoante os mecanismos adotados com base, de preferência, no principio da mais alta racionalidade institucional possível.

"Governo de partido, de opinião, de maioria e de representação, ele se acha normalmente impregnado de alto teor de legitimidade e basta isso238para fazê-lo idôneo a enfrentar e absorver crises,

repartindo por todos, sem injustiça, o ônus político, econômico e social dos sacrifícios exigidos à nação" ("Parlamentarismo ou Presidencialismo?", ob. Cit. p. 127/8).

18 A Comissão é assim constituída: Presidente: Ives Gandra da Silva Martins, Vice-presidente: José Afonso da Silva, Membros Efetivos: Alberto Lopes Mendes Rollo, Alexandre de Moraes, Almino Monteiro Álvares Affonso, André Ramos Tavares, Antonio Carlos Rodrigues do Amaral, Antônio Márcio da Cunha Guimarães, Carmen Silvia Valio de Araújo, Claudio Salvador Lembo, Dalmo de Abreu Dallari, Dirceo Torrecillas Ramos, Evandro Herrera Bertone Gussi, José de Ávila Cruz, José Gregori, Maria Garcia, Nelson Jobim, Ney Prado, Paulo de Barros Carvalho, Robson Maia Lins e Samantha Ribeiro Meyer-Pflug.

${ }^{19}$ Manoel Gonçalves Ferreira Filho ensina:

"Probidade na Administração. A probidade é uma obrigação elementar, a que todos, especialmente os que recebem, administram e aplicam dinheiro público, estão jungidos. O Presidente da República, evidentemente, não escapa a essa obrigação. Desse modo, tem de zelar para que toda a administração pública se atenha estritamente às normas de probidade, sobretudo financeira" (grifos meus) (Comentários à Constituição Brasileira de 1988, volume I, Ed. Saraiva, São Paulo, p. 455).

Revista de Direito Brasileira | São Paulo, SP | v. 14 | n. 6 | p. 231 - 251 | maio/ago. 2016 
O texto constitucional deve ser examinado à luz da própria clareza do dispositivo, segundo o qual:

\author{
"constitui crime de responsabilidade" \\ "atos" \\ "contra a probidade da administração".
}

O primeiro aspecto a ser realçado é que o texto constitucional não discute o aspecto subjetivo de quem pratica os atos, isto é, se o autor é probo ou ímprobo, honesto ou desonesto na sua personalidade, na sua maneira de ser, e sim se, na condição de presidente, mesmo que seja um cidadão honesto e digno, praticou, por qualquer razão, atos contra a probidade. Não propriamente atos de improbidade, mas atos contra a "probidade de administração". Isto vale dizer que, se seus atos provocaram problemas administrativos envolvendo administração ímproba, ou seja, se seu procedimento concorreu para gerar efeitos contrários à lisura da administração proba, digna e honesta, está, o presidente, sujeito ao processo, mesmo que seja um cidadão digno $^{20}$. Creio que, por esta razão, o constituinte, ao falar em crimes de responsabilidade, não distinguiu os crimes dolosos dos culposos.

Aliás, é da tradição do direito brasileiro que quem está no comando de qualquer empreendimento, responda por atos culposos e dolosos, como ocorre, por exemplo, na responsabilidade tributária, dos artigos 134 e 135 do CTN, ou naquela prevista na lei das sociedades por ações, segundo a qual os conselhos de administração, são responsáveis, em processos falimentares ou de recuperação das empresas, tanto por atos dolosos, quanto $\operatorname{culposos}^{21}$.

${ }^{20}$ Alexandre de Moraes lembra que:

"A Constituição de Filadélfia já previa o instituto do impeachment (art. $1^{\circ}$, Seção $3^{\text {a }}$; art. $2^{\circ}$, Seção $4^{\mathrm{a}}$ ), que nos Estados Unidos da América foi tentado contra o Presidente

Andrew Johnson, em 1868, sem êxito, e, mais recentemente, no famoso caso Watergate, tendo o Presidente Nixon renunciado antes de se iniciar o processo, e contra o Presidente Bill Clinton, também sem sucesso.

No Brasil, as Leis $\mathrm{n}^{\circ}$ s 27 e 30, de 1892, regulamentadoras dos crimes de responsabilidades cometidos pelo Presidente da República, previam a aplicação somente da pena de perda do cargo, podendo esta ser agravada com a pena de inabilitação para exercer qualquer outro cargo (art. 33, § $3^{\circ}$, da Constituição Federal de 1891; art. $2^{\circ}$ da Lei $n^{\circ} 30$, de 1892), dando à pena de inabilitação o caráter de pena acessória (Lei no 27 de 1892, arts. 23 e 24).

Atualmente, a Lei ${ }^{\circ} 1.079 / 50$, em seus arts. $2^{\circ}, 31,33$ e 34, não prevê a possibilidade da aplicação só da pena de perda do cargo, nem a pena de inabilitação assume caráter de acessoriedade (art. 52, parágrafo único, da Constituição de 1988), devendo, ambas, serem aplicadas cumulativamente" (Constituição do Brasil interpretada e legislação constitucional, Ed. Atlas, São Paulo, 2013, p. 1271)

${ }^{21}$ Estão os artigos mencionados assim redigidos:

“Art. 134. Nos casos de impossibilidade de exigência do cumprimento da obrigação principal pelo contribuinte, respondem solidariamente com este nos atos em que intervierem ou pelas omissões de que forem responsáveis:

I - os pais, pelos tributos devidos por seus filhos menores;

II - os tutores e curadores, pelos tributos devidos por seus tutelados ou curatelados;

III - os administradores de bens de terceiros, pelos tributos devidos por estes;

IV - o inventariante, pelos tributos devidos pelo espólio;

V - o síndico e o comissário, pelos tributos devidos pela massa falida ou pelo concordatário;

VI - os tabeliães, escrivães e demais serventuários de ofício, pelos tributos devidos sobre os atos praticados por eles, ou perante eles, em razão do seu ofício;

VII - os sócios, no caso de liquidação de sociedade de pessoas.

Parágrafo único. O disposto neste artigo só se aplica, em matéria de penalidades, às de caráter moratório.

Art. 135. São pessoalmente responsáveis pelos créditos correspondentes a obrigações tributárias resultantes de atos praticados com excesso de poderes ou infração de lei, contrato social ou estatutos:

I - as pessoas referidas no artigo anterior;

II - os mandatários, prepostos e empregados;

III - os diretores, gerentes ou representantes de pessoas jurídicas de direito privado.";

Revista de Direito Brasileira | São Paulo, SP | v. 14 | n. 6 | p. 231 - 251 | maio/ago. 2016 
Cheguei a defender a tese, no que diz respeito à responsabilidade tributária, de que o artigo 135 contemplaria hipótese de dolo, por falar em responsabilidade pessoal, e o artigo 134, de culpa, por tornar solidária a responsabilidade, em relação aos autores da infração, tese, todavia, que não foi hospedada pelo Poder Judiciário.

A responsabilidade pessoal eximiria a empresa. Apesar de o artigo 135 fazer menção a "responsabilidade pessoal" nos atos dolosos dos administradores, tornou, o Judiciário, tal responsabilidade, apenas solidária.

O certo, todavia, é que, mesmo que não sejam ímprobos, desonestos, imorais os administradores de empresas, são eles responsabilizados por atos de gestão que possam implicar desvios de qualquer natureza. Tais atos, mais pelos seus resultados do que pela intenção, é que podem tornar o agente passível de responsabilização ${ }^{22}$.

Assim sendo, culposos ou dolosos, atos que são contra a probidade da administração podem gerar o processo político de impeachment.

\section{DA RESPONSABILIDADE OBJETIVA DO ESTADO E SUBJETIVA DO AGENTE PÚBLICO}

O segundo dispositivo a ser examinado é o do artigo $37, \S 6^{\circ}$, da $\mathrm{CF} / 88$, assim redigido:

$\S 6^{\circ}$ - As pessoas jurídicas de direito público e as de direito privado prestadoras de serviços públicos responderão pelos danos que seus agentes, nessa qualidade, causarem a terceiros, assegurado o direito de regresso contra o responsável nos casos de dolo ou culpa ${ }^{23}$.

Há de se destacar, no referido dispositivo, três tipos de responsabilidade, ou seja: objetiva, por culpa ou por dolo.

A primeira é de ser aplicada, exclusivamente à instituição pública ou a entidades a ela vinculadas. As duas últimas, hipóteses aplicáveis ao agente, quanto à obrigação de ressarcir o Poder Público pelo ato lesivo causado à sociedade.

\footnotetext{
“Art. 158 da Lei das S/As: Art. 158. O administrador não é pessoalmente responsável pelas obrigações que contrair em nome da sociedade e em virtude de ato regular de gestão; responde, porém, civilmente, pelos prejuízos que causar, quando proceder:

I - dentro de suas atribuições ou poderes, com culpa ou dolo; (grifos meus)

II - com violação da lei ou do estatuto".

22 Modesto Carvalhosa, em seu artigo "O crime consumado de responsabilidade" (jornal O Estado de São Paulo, 22/12/2014, p. A2), entende que a omissão da presidente em punir responsáveis já caracteriza crime consumado de responsabilidade:

"Isso quer explicitamente dizer que a Senhora presidente não vai abrir processos penais administrativos contra as empreiteiras envolvidas nos crimes cometidos na empresa estatal, na conformidade com a Lei Anticorrupção. Com isso incorre a presidente da República no crime de responsabilidade previsto no artigo 85 da Constituição. Literalmente: "São crimes de responsabilidade os atos do presidente da República que atentem contra a Constituição Federal e, especialmente, contra: (...) VII - o cumprimento das leis".

${ }^{23}$ Caio Mário da Silva Pereira lembra que:

"E a Constituição Federal assenta que as pessoas jurídicas de direito público responderão pelos danos que seus funcionários, nessa qualidade, causaram a terceiros, cabendo ação regressiva contra o funcionário responsável, nos casos de culpa ou dolo (Emenda Constitucional n 1, de 1969, art. 107 e seu parágrafo único; Constituição Federal de 5 de outubro de 1988, art. 37, $\mathrm{n}^{\circ}$ XXI, $\S 6$ ), segundo o qual a teoria do risco integral compreende as pessoas jurídicas de direito público, bem como as de direito privado prestadoras de serviços públicos.

É pacífico, e já requer maior explanação, que os vocábulos, "representantes" e "funcionários" não são usados em acepção estrita, porém ampla, naquele sentido acima assentado, de quem no momento exercia uma atribuição ligada à sua atividade ou à sua função.

É de se entender, igualmente, que no vocábulo "estado" compreende-se as pessoas jurídicas de direito público e as de direito privado prestadoras de serviços públicos" (Responsabilidade Civil, $2^{a}$ edição, ed. Forense, 1990, p. 139).
}

Revista de Direito Brasileira | São Paulo, SP | v. 14 | n. 6 | p. 231 - 251 | maio/ago. 2016 
Na responsabilidade objetiva, basta a existência do nexo de causalidade entre o ato e a lesão, para que o Poder Público possa ser responsabilizado, independente de culpa ou dolo. Neste ponto, afastou, o constituinte, a responsabilidade do agente.

Já no caso em que o agente público pratica o ato com culpa ou dolo, é ele quem, em última análise, pode ser responsabilizado ao final, mediante o exercício, pelo Estado, do direito de regresso.

A culpa caracteriza-se pela negligência, imperícia ou omissão.

Quando, na administração pública, o agente público permite que toda a espécie de falcatruas sejam realizadas sob sua supervisão ou falta de supervisão, caracteriza-se a atuação negligente e a improbidade administrativa por culpa. Quem é pago pelo cidadão para bem gerir a coisa pública e permite seja dilapidada por atos criminosos, é claramente negligente e deve responder por esses $\operatorname{atos}^{24}$. O mesmo se diga da imperícia. Se alguém se habilita a ser administrador público e não está preparado para o cargo, deixando de bem gerir a coisa pública, permitindo que subordinados e terceiros saqueiem o patrimônio dos cidadãos com atos de clara improbidade, à evidência, comete o crime culposo da improbidade. Por fim, a omissão constitui uma terceira forma de crime culposo de improbidade. Um administrador que se omite em conhecer o que está ocorrendo com seus subordinados, permitindo que haja desvios de recursos da sociedade para fins ilícitos, comete crime de responsabilidade administrativa culposa. Sua omissão é que permite ocorra à lesão ao patrimônio público.

Aliás, a Lei no 8.429 de 02/06/1992 claramente caracteriza a omissão como ato de improbidade:

Art. 11. Constitui ato de improbidade administrativa que atenta contra os princípios da administração pública qualquer ação ou omissão que viole os deveres de honestidade, imparcialidade, legalidade, e lealdade às instituições, e notadamente:

I - praticar ato visando fim proibido em lei ou regulamento ou diverso daquele previsto, na regra de competência ${ }^{25}$; (grifo meu).

E, à evidência, tal responsabilização é aplicável a todo administrador público provocador da lesão, não só dando azo a que o Poder Público exerça contra ele o direito de regresso pelos danos que o Estado tiver que suportar, mas ao direito da própria sociedade de vê-lo afastado da gestão da coisa pública, pois é quem mantém seus governantes com o pagamento de tributos desviados para fins ilícitos ${ }^{26}$.

24 Maria Helena Diniz lembra que:

“CULPA. 1. Direito administrativo. Não-cumprimento do dever pelo agente público, gerando responsabilidade civil do Estado. 2. Direito civil. Fundamento da responsabilidade civil, que, em sentido amplo, constitui a violação de um dever jurídico imputável a alguém, em decorrência de fato intencional ou de omissão de diligência ou cautela, compreendendo o dolo e a culpa. 3. Direito penal. É aquela cometida pelo agente ao deixar de empregar a atenção ordinária a que estava obrigado, prevendo o resultado danoso, agindo com imprudência, negligência ou imperícia. Ocorre, portanto, quando o agente dá causa ao resultado por imprudência, negligência ou imperícia, inobservando o dever de cuidado que se lhe impunha” (Dicionário Jurídico, volume 1, Ed. Saraiva, São Paulo, 1998, p. 962).

25 Apesar da crítica de alguns juristas à abrangência do artigo, continua vigendo, sem ter sua inconstitucionalidade declarada.

26 José Cretella Jr. esclarece:

“Agente público (ou agente administrativo) é expressão técnica há muito empregada na terminologia do direito público (Duguit, Jèze, Bonnard, Staïnof) para designar todo indivíduo que participa de maneira permanente, temporária ou acidental, da atividade do Estado, quer editando atos jurídicos, quer executando atos de natureza técnica e material.

A expressão abrange não apenas os indivíduos dos quadros do Estado ou dos corpos locais, em virtude de título de direito público, isto é, os que são designados para executar funções pertinentes ao domínio do direito público, mas também, em geral, todos os que, sem distinção de função, são chamados, de um modo ou doutro, para colaborar no

Revista de Direito Brasileira | São Paulo, SP | v. 14 | n. 6 | p. 231 - 251 | maio/ago. 2016 


\section{DA AÇÃO DE REGRESSO}

Tais considerações levam-me, agora, ao terceiro dispositivo a ser examinado, a saber: o $\S 5^{\circ}$, do artigo 37 , assim redigido:

$\S 5^{\circ}$ - A lei estabelecerá os prazos de prescrição para ilícitos praticados por qualquer agente, servidor ou não, que causem prejuízos ao Erário, ressalvadas as respectivas acões de ressarcimento. ${ }^{27}$ (grifos meus).

Tal artigo traz uma novidade, não comum ao direito, qual seja a imprescritibilidade das ações de regresso do Poder Público contra o agente público que gera o prejuízo ao Estado, POR CULPA OU DOLO.

A prescrição ao direito de ação é forma de dar segurança ao direito e estabilidade às relações jurídicas. Se um direito não for exercido por um determinado período, perde o titular a faculdade de acionar aquele contra quem teria a possibilidade de agir ${ }^{28}$.

É que a garantia das relações jurídicas e a estabilidade da ordem legal impõem prazo para que se possa fazer prevalecer direitos, findo o qual, tais direitos, de rigor, perecem, pela impossibilidade de ser exigida em juízo sua efetivação. Por isto, entendem autores renomados que a prescrição é instituto de direito material e não processual, pois seu não uso no tempo legalmente previsto, acarreta, de rigor, o perecimento do direito de ação ${ }^{29}$.

funcionamento dos serviços dos corpos públicos (Staïnof, Le fonctionnaire, 1933, p. 25; e nosso Tratado, 1967, vol. 4, p. 71).

Assim, a expressão agente público é muito mais extensa que a expressão servidor público e que funcionário público e compreende, além dos funcionários públicos propriamente ditos, uma infinidade de outros indivíduos que agem em nome do Estado (cf. nosso Tratado de direito administrativo, 1967, vol. 4, p. 72)." ("Comentários à Constituição 1988", volume IV, Forense Universitária, Rio de Janeiro, 1991, p. 2351).

${ }^{27}$ Pinto Ferreira preleciona:

"Conforme informam os grandes tratadistas europeus, como Paul

Errera e Léon Duguit, os tribunais condenam os servidores quando agem desonestamente, ou com negligência e culpa. O Estado então indeniza o dano causado pelos seus servidores, adotando-se hoje no País a doutrina da responsabilidade objetiva.

O Estado pode ser obrigado ao ressarcimento do dano causado

sempre que ocorre a culpa in eligendo, a culpa in vigilando e a culpa 'in omittendo', sem prejuízo de sua responsabilidade objetiva.

A propósito escreve Carlos Maximiliano: "O agente da Administração é o órgão da pessoa jurídica de Direito Público. Ora, toda pessoa moral responde pelos atos dos seus órgãos, que são os próprios atos.

Quando o funcionário atua como tal, é a pessoa jurídica de Direito Público, ela própria, que age. O princípio universal decorre da concepção mesmo da personalidade moral; a pessoa coletiva age por meio de seus órgãos; os atos destes são os seus, daí a sua responsabilidade" ("Comentários à Constituição Brasileira", $2^{\circ}$ volume, Ed. Saraiva, São Paulo, 1990, p. 404).

${ }_{28}$ Manoel Gonçalves Ferreira Filho critica a disposição:

"Prescrição. Parecem deduzir-se duas regras deste texto mal redigido. Uma, concernente à sanção pelo ilícito; outra, à reparação do prejuízo. Quanto ao primeiro aspecto, a norma "chove no molhado": prevê que a lei fixe os respectivos prazos prescricionais. Quanto ao segundo, estabelece-se de forma tangente a imprescritibilidade das acões visando ao ressarcimento dos prejuízos causados" (grifos meus) (Comentários à Constituição Brasileira de 1988, vol. 1, Ed. Saraiva, $3^{\text {a }}$. ed., 2000, p. 259).

${ }^{29}$ Coordenei dois Simpósios nacionais sobre decadência e prescrição, que embora versando matéria tributária, todos os autores cuidaram dos institutos. Coordenei a publicação de dois livros: em 1976 ( $1^{\circ}$ Simpósio) "Decadência e Prescrição - Caderno de Pesquisas Tributárias volume 1" (Ed. Resenha Tributária, 3ª tiragem, 1991) tendo como autores: Aires Fernandino Barreto, Bernardo Ribeiro de Moraes, Carlos da Rocha Guimarães, Edvaldo Brito, Fábio Fanucchi, Francisco de Assis Praxedes, Ives Gandra Martins, José Carlos Graça Wagner, Leonel de Andrade Velloso, Noé Winkler, Paulo de Barros Carvalho, Rafael Moreno Rodrigues, Roberto Oscar Freytes, Rubens Approbato Machado, Sebastião de Oliveira Lima e Ylves José de Miranda Guimarães e, em 2007 (32 Simpósio) o livro "Decadência e Prescrição - Pesquisas Tributárias Nova Série 13" (Ed. Revista dos Tribunais) com os autores: André Costa-Corrêa, Carlos Henrique Abrão, Edison Carlos Fernandes, Eduardo Junqueira Coelho, Fátima Revista de Direito Brasileira | São Paulo, SP | v. 14 | n. 6 | p. 231 - 251 | maio/ago. 2016 
Ora, o dispositivo mencionado admite a prescrição MENOS PARA AS LESÕES PRATICADAS POR CULPA OU DOLO CONTRA O ESTADO, o que vale dizer, o agente público que por omissão, imperícia ou negligência causar prejuízo permitindo desvios de dinheiro público praticados por seus subordinados, responde até o fím da vida pelos atos omissivos (quando os atos propiciaram, por não detectados, a consumação da lesão) ou comissivos (propiciaram a lesão) praticados.

Considerou, o constituinte, tão grave a má administração por imperícia, negligência ou omissão, que seu agente poderá sofrer a ação de regresso até o fim da vida, pois, para tal inabilidade gestora, não há prescrição no direito do estado de demandar contra o agente. $\mathrm{O}$ direito é do Estado, enquanto representando a sociedade; não do Governo, que pode estar envolvido na lesão praticada.

Não sem razão, a Lei $\mathrm{n}^{\circ} 8.249 / 92$, que trata de improbidade administrativa, colocou a ação ou omissão como forma de responsabilidade. E, certamente, por essa razão, pela gravidade da ação ou omissão, tornou, o constituinte, imprescritível sua responsabilidade ${ }^{30}$.

Sobre o crime doloso, há pouco a falar. Se a própria autoridade praticou, conscientemente, o ato de improbidade com dolo, fraude, simulação, enfim, com má-fé, à evidência, comprovado o crime, a prova inequívoca torna o ato claramente violentador do princípio da moralidade, alicerce maior dos cinco princípios fundamentais da administração ${ }^{31}$.

Poder-se-ia dizer, todavia, que esta responsabilidade é civil e não penal e que a Constituição cuida de crimes contra a probidade na administração. Como mostrei anteriormente, o próprio constituinte declarou que os atos contra probidade na administração é que seriam tidos por criminosos, pois, do resultado desses atos é que se afere a improbidade administrativa.

A própria lei do impeachment, que vem da década de 50, tendo tido pequenas alterações após 88, e que foi pela lei suprema recepcionada, estabelece (Lei 1.079/50, acrescentada pela Lei 10.028/00) em seu artigo $9^{\circ}$, que:

Art. $9^{\circ}$ São crimes de responsabilidade contra a probidade na administração:

(...) 3 - não tornar efetiva a responsabilidade dos seus subordinados, quando manifesta em delitos funcionais ou na prática de atos contrários à Constituição; (...).

Ora, o crime in eligendo ou in vigilando é, claramente, caracterizado pela falha do administrador público que, diante de indícios fortes, com prejuízos detectados nos atos

Fernandes Rodrigues de Souza, Fernanda Hernandez, Hugo de Brito Machado, Hugo de Brito Machado Segundo, Humberto Martins, Ives Gandra Martins, Jorge de Oliveira Vargas, José Eduardo Soares de Melo, Kiyoshi Harada, Leonardo de Faria Galiano, Marilene Talarico Martins Rodrigues, Octavio Campos Fischer, Ricardo Lobo Torres, Sacha Calmon Navarro Coelho, Schubert de Farias Machado e Vittorio Cassone.

30 Celso Bastos, como Manoel Gonçalves, lamenta a imprescritibilidade, mas cita Wolgran Junqueira, que leva a responsabilidade a herdeiros na herança recebida:

"No que tange aos danos civis, o propósito do texto é de tornar imprescritíveis as ações visando o ressarcimento do dano causado. É de lamentar-se a opção do constituinte por essa exceção à regra da prescritibilidade, que é sempre encontrável relativamente ao exercício de todos os direitos. Wolgran Junqueira Ferreira levanta o problema consistente em saber se os herdeiros do causador do ilícito respondem pelos prejuízos causados pelo 'de cujus'. Seu ponto de vista é de que "sim, na força de sua herança, pois esta é, em tese, fruto daquele ilícito" (Comentários à Constituição de 1988, $1^{\text {a }}$. Ed., Julex, 1989, v. 1, p. 479)" (Comentários à Constituição do Brasil, volume 3, tomo III, Ed. Saraiva, 1992, p. 167).

31 Estão consagrados no "caput" do artigo 37 da Lei Suprema:

"Art. 37. A administração pública direta e indireta de qualquer dos Poderes da União, dos Estados, do Distrito Federal e dos Municípios obedecerá aos princípios de legalidade, impessoalidade, moralidade, publicidade e eficiência e, também, ao seguinte: ...”. 
administrativos praticados sob sua supervisão, deixa de tornar efetiva a responsabilização de seus subordinados $^{32}$.

Em outras palavras, a demonstração da lesão ao cidadão (no caso da Petrobrás, por exemplo, todos os acionistas privados foram lesados) ou à sociedade (a sociedade como um todo, pagadora de tributos e acionista, por meio da União, da referida estatal), é suficiente para conformar a aplicação do dispositivo infraconstitucional de crime contra a probidade da administração, estatuído no artigo $9^{\circ}$ inciso 3 da Lei 1079/50 (Lei 10.028/00).

Mesmo que não houvesse o dispositivo infraconstitucional - que diz menos que a própria lei suprema - seria a Lei Maior auto-aplicável e os crimes contra a probidade de administração, culposos ou dolosos, praticados por quem está no comando da Nação, poderiam dar causa à abertura de eventual processo - que, reitero, é mais político que jurídico - do impeachment ${ }^{33}$.

32 O TRF da $1^{\text {a }}$. Região publicou três volumes sobre "A Constituição na visão dos Tribunais - Interpretação e julgados artigo por artigo" (Ed. Saraiva, São Paulo, 1997). Em relação aos $\S \S 5^{\circ}$ e $6^{\circ}$ do artigo 37 lê-se:

“- Silvio Rodrigues preleciona acerca da regra geral da responsabilidade civil: "Princípio geral de direito, informador de toda a teoria da responsabilidade, encontradiço no ordenamento jurídico de todos os povos civilizados e sem o qual a vida social é quase inconcebível, é aquele que impõe, a quem causa dano a outrem, o dever de o reparar. Tal princípio se encontra registrado, entre nós, no art. 159 do Código Civil." (Direito Civil - Responsabilidade Civil, volume 4, 140 ed. atualizada, São Paulo: Saraiva, 1995, p. 13.) O mesmo autor dá a notícia de que o legislador brasileiro, certamente, inspirou-se no art. 1.382 do Código Civil francês. O art. 1.382 do Código Napoleônico está vazado nestes termos: "Tout fait quel conque de l'homme, qui cause à autrui un dommage, oblige celui par la faute duquel il est arrivé, à la réparer".

- O presente dispositivo cuida da responsabilidade estatal em face de ato de um de seus prepostos. J. Cretella Júnior bem sintetiza a questão: "O problema da responsabilidade civil do Estado pode ser equacionado nos seguintes termos: se um funcionário, que é parte do Estado e que se acha na posição de seu preposto, causa danos à propriedade ou à incolumidade de terceiros, mediante ação ou omissão, como responde o Estado pelos prejuízos advindos?" (Curso de Direito Administrativo, 11' ed., Rio de Janeiro: Forense, 1992, p. 84.) (Grifos no original.) O ilustre administrativista responde à questão a partir da constatação de que a solução se inicia pelo afastamento dos "termos civilistas" e pelo enfrentamento da questão sob a égide dos princípios informativos do Direito Público. O grande marco dessa nova postura, segundo o autor, foi o famoso caso Blanco, decidido em 1973 pelo Tribunal de Conflitos, na França. Vide, a respeito, op. cit., pp. 84/85.

J. Cretella Junior, com base nos princípios publicísticos, traz à baila três teorias explicativas da responsabilidade civil do Estado: teoria da culpa administrativa, teoria do acidente administrativo e teoria do risco integral.

- A responsabilidade civil do Estado é demonstrada pela teoria da responsabilidade objetiva, que prescinde da avaliação dos elementos subjetivos, ou seja, dolo ou culpa. Maria Sylvia Zanella Di Pietro bem elucida o tema: "é também chamada teoria do risco, porque parte da idéia de que a atuação estatal envolve um risco de dano, que lhe é inerente." (Direito Administrativo, 2' ed., São Paulo: Atlas, 1991, p. 358.) (Grifo no original.) A mesma autora adverte para o fato de haver uma classificação da teoria do risco: risco administrativo e risco integral, conforme preconiza Hely Lopes Meirelles. Entretanto, segundo Di Pietro, "a maior parte da doutrina não faz distinção". (Idem.)

- Em artigo publicado na Revista do TRF - 1 'Região, v.8 n.1, Ives Gandra da Silva Martins evidencia, em linhas gerais, a divergência existente. Em nota de rodapé, ele afirma: "Caio Mário da Silva Pereira acentua: 'o direito positivo brasileiro consagra a teoria do risco integral ou risco administrativo ...."' Mais adiante, em outra nota, o autor noticia: "Toshio Mukai ensina sobre o $\$ 62$ do artigo 37: 'A norma contempla o tema da responsabilidade civil do Estado.... com assento na teoria do risco administrativo (que admite excludentes: a culpa da vítima ou a força maior), e não a do risco integral (que inadmite excludentes)." ("A mora de sociedade de economia mista acionada por prestadora de serviços com acordo a ser firmado em juízo, com garantia de adimplência ofertada por sua acionista controladora, a Prefeitura Municipal de Paulínia - parecer - Revista, pp. 73/87)" (p. 459/60).

33 A Suprema Corte, todavia, no caso do "impeachment" do Presidente Collor, em mandado de segurança, afastou a tese de Paulo Brossard que a matéria não deveria ser examinada pela Suprema Corte por ser política:

"Importante ressaltar que, no referido mandado de segurança, restou superada tese, sustentada pelo Ministro Paulo Brossard, no sentido da não-cognoscibilidade do mandado de segurança em razão do caráter eminentemente político da controvérsia" (Curso de Direito Constitucional, Gilmar Mendes e Paulo Gonet, Ed. Saraiva e Instituto Brasiliense de Direito Público, São Paulo, p. 880).

Revista de Direito Brasileira | São Paulo, SP | v. 14 | n. 6 | p. 231 - 251 | maio/ago. 2016 


\section{DA JURISPRUDÊNCIA}

Tenho consciência de que o entendimento de que não só o dolo, mas também a culpa grave pode constituir crime de improbidade administrativa, podendo até mesmo ser base para um pedido de impeachment, é aparentemente polêmico. Grande parte dos juristas, não voltados à área de direito constitucional ou administrativo, entende que apenas o dolo poderia justificar o crime de improbidade e eventual pedido de impeachment.

Minha tese, todavia, lastreia-se em acórdão do STF, declarando constitucional a lei dos crimes contra a probidade da administração, como se vê da ementa a seguir transcrita:

AÇÃO DIRETA DE INCONSTITUCIONALIDADE. 1. QUESTÃO DE ORDEM: PEDIDO ÚNICO DE DECLARAÇÃO DE INCONSTITUCIONALIDADE FORMAL DE LEI. IMPOSSIBILIDADE DE EXAMINAR A CONSTITUCIONALIDADE MATERIAL. 2. MÉRITO: ART. 65 DA CONSTITUIÇÃO DA REPÚBLICA. INCONSTITUCIONALIDADE FORMAL DA LEI 8.429/1992 (LEI DE IMPROBIDADE ADMINISTRATIVA): INEXISTÊNCIA.

1. Questão de ordem resolvida no sentido da impossibilidade de se examinar a constitucionalidade material dos dispositivos da Lei 8.429/1992 dada a circunstância de o pedido da ação direta de inconstitucionalidade se limitar única e exclusivamente à declaração de inconstitucionalidade formal da lei, sem qualquer argumentação relativa a eventuais vícios materiais de constitucionalidade da norma.

2. Iniciado o projeto de lei na Câmara de Deputados, cabia a esta o encaminhamento à sanção do Presidente da República depois de examinada a emenda apresentada pelo Senado da República. O substitutivo aprovado no Senado da República, atuando como Casa revisora, não caracterizou novo projeto de lei a exigir uma segunda revisão.

3. Ação direta de inconstitucionalidade improcedente ${ }^{34}$.

Conta, também, como o respaldo de decisões do Superior Tribunal de Justiça, proferidas nos seguintes julgados:

1) REsp: 816193 - EMENTA:

PROCESSO CIVIL E ADMINISTRATIVO. IMPROBIDADE ADMINISTRATIVA. ALEGADA AFRONTA AO ART. 535 E 458 DO CPC. INOCORRENNCIA. CONFIGURAÇÃO DO ATO DE IMPROBIDADE DO ART. 10, INCISO X, SEGUNDA PARTE, DA LEI 8.429/92. POSSIBILIDADE DE ELEMENTO SUBJETIVO DA CULPA NAS CONDUTAS DO ART. 10. DEMONSTRAÇÃO DO ELEMENTO SUBJETIVO CULPOSO E PREJUÍZO AO ERÁRIO PRESENTES NO ACÓRDÃO A QUO. RECURSO PROVIDO.

1. O aresto recorrido não está eivado de omissão nem de contradição, pois resolveu a matéria de direito valendo-se de elementos que julgou aplicáveis e suficientes para a solução da lide, havendo, na verdade, mero inconformismo em relação aos fundamentos da decisão.

2. A alegação de ofensa aos arts. $1^{\circ}, 5^{\circ}$ e 10 , inciso $X$, da Lei $8.429 / 92$ merece acolhida, pois o acórdão recorrido deixou assente a existência de dano ao erário por responsabilidade do prefeito municipal, à época ordenador de despesas, configurando-se ato de improbidade administrativa.

3. A decisão recorrida reconheceu claramente a responsabilidade do ex-prefeito Nelson Jorge Maia quanto à realização de obras ineficazes para solução do

\footnotetext{
${ }^{34}$ STF - ADI: 2182 DISTRITO FEDERAL 0001135-18.2000.0.01.0000, Relator: Min. MARCO AURÉLIO, Data de Julgamento: 12/05/2010, Tribunal Pleno, Data de Publicação: 10/09/2010.
}

Revista de Direito Brasileira | São Paulo, SP | v. 14 | n. 6 | p. 231 - 251 | maio/ago. 2016 
acúmulo e proliferação de substância conhecida por necrochorume que traz sérios e graves riscos à saúde e à segurança da população, causando efetivamente lesão ao erário do município de Passos/MG.

4. Doutrina e jurisprudência pátrias afirmam que os tipos previstos no art. 10 e incisos (improbidade por lesão ao erário público) prevêem a realização de ato de improbidade administrativa por ação ou omissão, dolosa ou culposa. Portanto, há previsão expressa da modalidade culposa no referido dispositivo, não obstante as acirradas críticas encetadas por parte da doutrina.

5. Restou demonstrada na fundamentação do acórdão atacado a existência do elemento subjetivo da culpa do ex-prefeito bem como o prejuízo que a negligência causou ao erário, caracterizando-se, por isso mesmo, a tipicidade de conduta prevista no art. 10, inc. X, segunda parte, da Lei 8.429/92.

6. Recurso especial provido para restabelecer a condenação do ex-prefeito do município de Passos/MG - Nelson Jorge Maia ao ressarcimento integral do dano, atualizado monetariamente pelos índices legais acrescido de juros de mora na taxa legal, nos termos do art. 12, inc. II, da Lei 8.429/92 $2^{35}$.

\section{2) AgRg no Ag: 1375364 - EMENTA:}

PROCESSUAL CIVIL. ADMINISTRATIVO. OMISSÃO INEXISTENTE. INCONFORMISMO COM A TESE ADOTADA. DANO AO ERÁRIO. FORMA CULPOSA. ATO DE IMPROBIDADE ADMINISTRATIVA. CONFIGURAÇÃO.

1. Inexistente a alegada violação do art. 535, inciso II, do CPC, pois a prestação jurisdicional foi dada na medida da pretensão deduzida, como se depreende da leitura do acórdão recorrido, que enfrentou o tema abordado no recurso de apelação.

2. Na verdade a questão não foi decidida conforme objetivava a recorrente, uma vez que foi aplicado entendimento diverso. Contudo, decisão contrária ao interesse da parte não se confunde com omissão (REsp 10617/RS, rel. Min. Denise Arruda, Primeira Turma, julgado em 15.12.2009, DJe 2.2.2010).

3. Com efeito o acórdão proferido pelo Tribunal de origem não merece qualquer censura. Primeiro, porque não há omissão no julgado. Segundo, porque a jurisprudência do Superior Tribunal de Justiça reconhece que o ato de improbidade administrativa não exige a ocorrência de enriquecimento ilícito, sendo a forma culposa apta a configurá-lo.

Agravo regimental improvido ${ }^{36}$.

Em ambos, a Suprema Corte da legalidade, houve por bem consagrar a tese de que culpa grave (omissão, imperícia, negligência ou imprudência) pode configurar crime de improbidade administrativa, sob a regência da lei de 1992. Minha argumentação segue, pois, esta mesma linha de raciocínio.

\section{DOS FATOS CONCRETOS}

Os fantásticos desvios de recursos da Petrobrás, em atos fraudulentos, que atingem, no mínimo, 10 bilhões de reais - um banco americano (Morgan) entendendo estar em 21 bilhões -, reconhecidos pela Presidência da República, confessados pela diretoria da Petrobrás e por pessoas que atuaram como intermediários nos desvios e que levaram à prisão para investigação e preventiva considerável número de pessoas vinculadas ao Estado, à estatal e ao segmento

\footnotetext{
${ }^{35}$ STJ - REsp: 816193 MG 2006/0015183-8, Relator: Ministro CASTRO MEIRA, Data de Julgamento: 01/10/2009, T2 - SEGUNDA TURMA, Data de Publicação: DJe: 21/10/2009, 2 pgs.

${ }_{36}$ STJ - AgRg no Ag: 1375364 MG 2010/0222887-9, Relator: Ministro HUMBERTO MARTINS, Data de Julgamento: 03/11/2011, T2 - SEGUNDA TURMA, Data de Publicação: DJe 11/11/2011.
}

Revista de Direito Brasileira | São Paulo, SP | v. 14 | n. 6 | p. 231 - 251 | maio/ago. 2016 
privado, formatam realidade já provada. Apenas não se sabe o nível de comprometimento de cada um dos acusados, conhecendo-se, entretanto, o comprometimento de alguns que se beneficiaram da delação premiada.

Tudo ocorreu, nestes ciclópicos valores, na gestão do Presidente Lula e da Presidente Dilma, por 9 anos (!!!), sendo que, na gestão do Presidente Lula, a ora Presidente da República era a presidente do Conselho de Administração que, por força da lei das sociedades anônimas, tem responsabilidade direta pelos prejuízos gerados à estatal durante sua gestão ${ }^{37}$.

Foi a própria presidente quem reconheceu que, em um negócio que envolvia quase 2 bilhões de dólares (!!!), se tivesse sido alertada sobre as cláusulas que assinou, não teria concordado com o negócio. Ora, esta grave omissão, em que não procurou aprofundar-se nas condições de celebração de negócio bilionário, demonstra, pelo menos, a ocorrência de culpa gestora, quando não negligência administrativa e imperícia, pois não se tratava, repito, de um negócio sem expressão, mas de um negócio relevante, de quase dois bilhões de dólares!!!

Parece-me, pois, que, em tese, o crime de responsabilidade culposa contra a probidade está caracterizado, pois quem tem a responsabilidade legal e estatutária de administrar, deixou de fazê-lo.

A questão que se coloca é saber se os atos de gestão da empresa praticados pela atual presidente durante o Governo Lula, poderiam contaminar os atos de seu novo mandato. Pareceme que duas linhas de raciocínio devem ser desenvolvidas.

A primeira delas é que, a manutenção da presidente Graça Foster - que fora alertada, segundo a imprensa, dos potenciais desvios sem ter feito nada para impedi-los - no cargo de presidente da Petrobrás, embora a notícia dos desvios tenha vindo a público antes de sua posse, torna a presidente da República a incursa no inciso III, do artigo $9^{\circ}$, da Lei 1.079/50, pois não

37 Os artigos 138, 139 e 142 da Lei das S/As estão assim redigidos:

"Art. 138. A administração da companhia competirá, conforme dispuser o estatuto, ao conselho de administração e à diretoria, ou somente à diretoria.

$\S 1^{\circ} \mathrm{O}$ conselho de administração é órgão de deliberação colegiada, sendo a representação da companhia privativa dos diretores.

$\S 2^{\circ}$ As companhias abertas e as de capital autorizado terão, obrigatoriamente, conselho de administração.

Art. 139. As atribuições e poderes conferidos por lei aos órgãos de administração não podem ser outorgados a outro órgão, criado por lei ou pelo estatuto. (...).

Art. 142. Compete ao conselho de administração:

I - fixar a orientação geral dos negócios da companhia;

II - eleger e destituir os diretores da companhia e fixar-lhes as atribuições, observado o que a respeito dispuser o estatuto;

III - fiscalizar a gestão dos diretores, examinar, a qualquer tempo, os livros e papéis da companhia, solicitar informações sobre contratos celebrados ou em via de celebração, e quaisquer outros atos; (grifos meus)

IV - convocar a assembléia-geral quando julgar conveniente, ou no caso do artigo 132;

$\mathrm{V}$ - manifestar-se sobre o relatório da administração e as contas da diretoria;

VI - manifestar-se previamente sobre atos ou contratos, quando o estatuto assim o exigir;

VII - deliberar, quando autorizado pelo estatuto, sobre a emissão de ações ou de bônus de subscrição;

VIII - autorizar, se o estatuto não dispuser em contrário, a alienação de bens do ativo não circulante, a constituição de ônus reais e a prestação de garantias a obrigações de terceiros;(Redação dada pela Lei nº 11.941, de 2009)

IX - escolher e destituir os auditores independentes, se houver",

tendo Gil da Costa Carvalho sobre o artigo 142 escrito:

"2- Cabe ao Conselho fixar a orientação geral dos negócios da companhia. Com observância do contido no estatuto, o Conselho traçará normas de ordem geral. Estabelecerá quais as atividades que devem ser incrementadas e aquelas que devem ser reduzidas ou extintas. Estabelecerá critérios a serem observados nas diversas operações. Traçará uma política salarial para os empregados. Decidirá pela ampliação ou redução de negócios, aberturas de filiais ou sucursais, ou pela política da contratação de representantes comerciais em diversas praças etc.

As normas traçadas têm que ser obedecidas pela diretoria, pois os diretores se encontram sob o comando e vigilância do Conselho" (Comentários à Lei das Sociedades por Ações, coordenadores Geraldo de Camargo Vidigal e Ives Gandra Martins, Ed. Forense Universitária, Rio de Janeiro, 1999, p. 459) (grifos meus). 
partiu para a responsabilização de quem conviveu com os autores dos desvios, durante a gestão comum, no último mandato do presidente Lula e no seu $1^{\circ}$ mandato ${ }^{38}$.

Parece-me, pois, que não se trata, no que diz respeito ao novo mandato, em que se mantém a mesma direção continuada da instituição do $1^{\circ}$ mandato, se não de um mandato continuado, o que levaria a possibilidade de considerar crime continuado contra a probidade da administração, por falta das medidas necessárias de afastamento imediato de quem dirigiu a estatal em setores estratégicos e agora na presidência da empresa, durante o período de assalto a estatal (Presidente Lula e Presidente Dilma).

Para mim, pelo menos, está caracterizado crime culposo por atos omissivos e comissivos contra a administração (negligência, imperícia e omissão), todos previstos na lei de improbidade contra a administração.

Há, na verdade, um crime continuado da mesma gestora da coisa pública, quer como presidente do conselho da Petrobrás, representando a União, principal acionista da maior sociedade de economia mista do Brasil, quer como presidente da República, ao quedar-se inerte e manter os mesmos administradores da empresa. Na minha particular visão, o $§ 4^{\circ}$ do artigo 37, é, no caso, plenamente aplicável:

$\S 4^{\circ}$ - Os atos de improbidade administrativa importarão a suspensão dos direitos políticos, a perda da função pública, a indisponibilidade dos bens e o ressarcimento ao erário, na forma e gradação previstas em lei, sem prejuízo da ação penal cabível ${ }^{39}$.

38 Wallace Paiva Martins Junior elenca controvérsia sobre a caracterização de atos de improbidade, mas expõe opinião, lastreado na inteligência do STJ, de que não consagrou o STF imunização de atos de improbidade administrativa para agentes com foro privilegiado:

"Mercê de o Supremo Tribunal Federal ter assentado que "os atos de improbidade administrativa são tipificados como crime de responsabilidade na Lei n. 1.079/1950, delito de caráter político-administrativo [...] o sistema constitucional brasileiro distingue o regime de responsabilidade dos agentes políticos dos demais agentes públicos. A Constituição não admite a concorrência entre dois regimes de responsabilidade político-administrativa para os agentes políticos: o previsto no art. $37, \S 4^{\circ}$ (regulado pela Lei n. 8.429/1992) e o regime fixado no art. 102, I, c (disciplinado pela Lei n. 1.079/1950)", julgou que "a lei 8.429/1992 regulamenta o art. 37, parágrafo $4^{\circ}$ da Constituição, que traduz uma concretização do principio da moralidade administrativa inscrito no caput do mesmo dispositivo constitucional. As condutas descritas na lei de improbidade administrativa, quando imputadas a autoridades detentoras de prerrogativa de foro, não se convertem em crimes de responsabilidade". E vem prestigiando essa última orientação"' porque a tese contrária não tem efeito vinculante e a condição de agentes políticos não os exonera do dever de probidade nem os exclui da esfera da plena incidência normativa da Lei $\mathrm{n}$. 8.429/92120, assinalando que o debate sobre a inaplicabilidade dessa lei aos agentes políticos é matéria infraconstitucional e constitui ofensa indireta à Constituição. O Superior Tribunal de Justiça decidiu que "excetuada a hipótese de atos de improbidade praticados pelo Presidente da República (art. 85, V), cujo julgamento se dá em regime especial pelo Senado Federal (art. 86), não há norma constitucional alguma que imunize os agentes políticos, sujeitos a crime de responsabilidade, de qualquer das sanções por ato de improbidade previstas no art. $37, \S 4^{\circ}$. Seria incompatível com a Constituição eventual preceito normativo infraconstitucional que impusesse imunidade dessa natureza" ("Tratado de Direito Administrativo", volume 2, coordenação Adilson Dallari, Carlos Valder do Nascimento e Ives Gandra Martins, Ed. Saraiva, São Paulo, 2013, p. 151/2).

39 José Afonso da Silva escreve:

"ATOS DE IMPROBIDADE ADMINISIRATIVA. A probidade administrativa é uma forma de moralidade administrativa que mereceu consideração especial pela Constituição, que pune o ímprobo com a suspensão de direitos políticos (art. 37, § $4^{\circ}$ ). A probidade administrativa consiste no dever do funcionário de "servir à Administração com honestidade, procedendo no exercido das suas funções sem aproveitar os poderes ou facilidades delas decorrentes em proveito pessoal ou de outrem a quem queira favorecer". Cuida-se de uma imoralidade administrativa qualificada. A improbidade administrativa é uma imoralidade qualificada pelo dano ao Erário e correspondente vantagem ao ímprobo ou a outrem. O texto constitucional vincula, notoriamente, os atos de improbidade administrativa ao dano ao Erário Público, tanto que uma das sanções impostas consiste no ressarcimento ao Erário, porque é essa sanção que reprime o desrespeito ao dever de honestidade que é da essência do conceito da probidade administrativa. $\mathrm{O}$ grave desvio de conduta do agente público é que dá à improbidade Revista de Direito Brasileira | São Paulo, SP | v. 14 | n. 6 | p. 231 - 251 | maio/ago. 2016 
Ocorre que, se vier a ser comprovado - o que eu só formulo como hipótese, visto que não se tem ainda conhecimento da totalidade dos fatos - que o dinheiro desviado foi para alimentar as candidaturas de seu partido e aquelas de seus aliados, inclusive a própria, para a Presidência da República, dinheiro este que teria, em tese, propiciado a sua eleição e a dos demais parlamentares, então a própria eleição estará contaminada $a b$ initio, justificando a conclusão de que atos contra a probidade de administração (dolosos) teriam permitido a vitória sobre seus adversários, tornando ilícito o pleito.

É evidente que esta é apenas uma hipótese de trabalho para este estudo, visto que o tema está sujeito à prova posterior ${ }^{40}$.

\section{CONCLUSÃO}

Ante todo o exposto, apesar de o impeachment, como visto, ser um processo a ser analisado mais política que juridicamente pelo Congresso Nacional, há elementos jurídicos para que seja proposto e admitido o impeachment da atual presidente da República, Dilma Rousseff perante a Câmara dos Deputados e Senado Federal.

Em síntese, se a existência de crime doloso contra a administração depende de prova a ser feita até o fim do processo de investigação e das denúncias já realizadas, os crimes culposos de imperícia, omissão e negligência, estão perfeitamente caracterizados nos anos em que ela atuou como presidente do Conselho de Administração e Presidente da República, permitindo o maior desvio de dinheiro público da sociedade já ocorrido na história do Brasil, só descoberto POR FORÇA, EXCLUSIVAMENTE, DA INDEPENDÊNCIA E AUTONOMIA DA POLÍCIA FEDERAL E DO MINISTÉRIO PÚBLICO FEDERAL, em suas investigações.

Sendo assim, entendo que a culpa é hipótese de improbidade administrativa, nos termos do artigo 85, inciso V, da Lei Suprema dedicada ao impeachment e que o artigo 11 da Lei 8.429/92, pela monumentalidade dos desvios de dinheiro público por anos, é mais do que suficiente para fundamentá-lo, independentemente dos que entendam que sua extensão é excessiva $^{41}$.

administrativa uma qualificação especial, que ultrapassa a simples imoralidade por desvio de finalidade" (Comentário contextual à Constituição, 7ª. Ed., Malheiros Editores, 2009, São Paulo, p. 353).

40 Em livro que prefaciei de Mauro Roberto Gomes de Mattos critica ele a excessiva abertura do artigo 11 da Lei 8429/92, ao dizer:

"Isto porque uma lei tão severa como a de improbidade administrativa, capaz de suspender direitos políticos, determinar a perda da função pública, a indisponibilidade dos bens e o ressarcimento ao erário (art. 37 , $\S 4^{\circ}$, da CF), traga em seu contexto que o descumprimento, por qualquer ação ou omissão, dos deveres de honestidade, imparcialidade, legalidade e lealdade às instituições, bem como as hipóteses exemplificadas nos incs. I ao VII do art. 11 , caracterizam a improbidade.

Há que se ter temperamentos ao interpretar a presente norma, pois o seu caráter é muito aberto, devendo, por esta razão, sofrer a devida dosagem de bom senso para que mera irregularidade formal, que não se configura como devassidão ou ato ímprobo, não seja enquadrado na presente lei, com severas punições" ("O limite da improbidade administrativa - O direito dos administrados dentro da Lei $n^{\circ}$ 8429/92", $2^{\mathrm{a}}$. Ed., Ed. América Jurídica, Rio de Janeiro, 2005, p. 382).

41 Os que alegam excessiva abrangência, não encontram respaldo no STF que só examinou a lei, à luz de sua inconstitucionalidade formal, afastando-a:

"EMENTA: AÇÃO DIRETA DE INCONSTITUCIONALIDADE. 1. QUESTÃO DE ORDEM: PEDIDO ÚNICO DE DECLARAÇÃO DE INCONSTITUCIONALIDADE FORMAL DE LEI. IMPOSSIBILIDADE DE EXAMINAR A CONSTITUCIONALIDADE MATERIAL. 2. MÉRITO: ART. 65 DA CONSTITUIÇÃO DA REPÚBLICA. INCONSTITUCIONALIDADE FORMAL DA LEI 8.429/1992 (LEI DE IMPROBIDADE ADMINISTRATIVA): INEXISTÊNCIA. 1. Questão de ordem resolvida no sentido da impossibilidade de se examinar a constitucionalidade material dos dispositivos da Lei 8.429/1992 dada a circunstância de o pedido da ação direta de inconstitucionalidade se limitar única e exclusivamente à declaração de inconstitucionalidade formal da lei, sem qualquer argumentação relativa a eventuais vícios materiais de constitucionalidade da norma. 
Concluo, pois, considerando que o assalto aos recursos da Petrobrás, perpetrado durante oito anos, de bilhões de reais, sem que a Presidente do Conselho e depois Presidente da República o detectasse, constitui omissão, negligência e imperícia, conformando a figura da improbidade administrativa, a ensejar a abertura de um processo de impeachment.

\section{BIBLIOGRAFIA}

BASTOS, Celso. Comentários à Constituição de 1988. São Paulo: Julex, 1989.

BASTOS, Celso/ MARTINS, Ives Gandra da Silva (COORD.). Parlamentarismo ou Presidencialismo?. Rio de Janeiro: Editora Forense/ AIDE, 1987.

BASTOS, Celso/ MARTINS, Ives Gandra da Silva (COORD.). Parlamentarismo ou Presidencialismo? - Série Realidade brasileira, 2a . ed., Rio de Janeiro: Ed. Forense, 1993.

BAUAB, José D’Amico. "Paulistânia Eleitoral - ensaios, memórias, imagens”, 80 anos do TRE-SP. São Paulo: Imprensa Oficial do Governo do Estado de São Paulo, 2011.

CRETELLA JÚNIOR, José. Comentários à Constituição de 1988. Rio de Janeiro, Forense Universitária, 1991. . Curso de Direito Administrativo. Rio de Janeiro, Forense Universitária, 1992.

DALLARI, Adilson. MARTINS, Ives Gandra da Silva. NASCIMENTO, Carlos Valder do Nascimento (COORD.). Tratado de Direito Administrativo. São Paulo: Ed. Saraiva, 2013.

DINIZ, Maria Helena. Dicionário Jurídico. Volume 1. São Paulo: Ed. Saraiva, 1998.

Direito tributário 2. São Paulo: José Bushatsky Editor, 1972.

FERRARA, Francesco. Interpretação e aplicação das leis. $2^{a}$. edição, Coimbra: Arménio Amado Editor, 1987.

FERREIRA FILHO, Manoel Gonçalves. Comentários à Constituição Brasileira de 1988, volume I. São Paulo: Ed. Saraiva, 2000.

FERREIRA, Luís Pinto. Comentários à Constituição Brasileira. $2^{\circ}$ volume, São Paulo: Ed. Saraiva, 1990.

GONET, Paulo. MENDES, Gilmar. Curso de Direito Constitucional. São Paulo: Ed. Saraiva e Instituto Brasiliense de Direito Público

LIJPHART, Arend. Democracies. New Haven, CN: Ed. Yale University Press, 1984.

2. Iniciado o projeto de lei na Câmara de Deputados, cabia a esta o encaminhamento à sanção do Presidente da República depois de examinada a emenda apresentada pelo Senado da República. O substitutivo aprovado no Senado da República, atuando como Casa revisora, não caracterizou novo projeto de lei a exigir uma segunda revisão. 3 . Ação direta de inconstitucionalidade improcedente.

(ADI 2182, Relator(a): Min. MARCO AURÉLIO, Relator(a) p/ Acórdão: Min. CÁRMEN LÚCIA, Tribunal Pleno, julgado em 12/05/2010, DJe-168 DIVULG 09-09-2010 PUBLIC 10709-2010 EMENT VOL-02414-01 PP-00129 RTJ VOL-00218-PP-00060)" (site do STF). 
MARTINS, Ives Gandra da Silva. O que é Parlamentarismo Monárquico. - Coleção Primeiros Passos 270. São Paulo: Editora Brasiliense, 1993.

. O Estado de Direito e o Direito do Estado. $2^{\mathrm{a}}$. ed. revista e ampliada. São Paulo: Ed.

Revista dos Tribunais, 2011.

. A era das contradições. São Luís: Livraria Resistencia Cultural, 2013.

. Uma visão do mundo contemporâneo. São Paulo: Pioneira, 1996.

. A nova classe ociosa. Rio de Janeiro: Forense/AIDE, 1987.

O Poder. São Paulo: Ed. Saraiva, 1984.

. O impeachment na Constituição de 1988. Belém do Pará: Ed. Cejup, 1992.

MARTINS, Ives Gandra da Silva (COORD.). Decadência e Prescrição. São Paulo: Caderno de Pesquisas Tributárias, 1976.

MARTINS, Ives Gandra da Silva (COORD.). Decadência e Prescrição. São Paulo: Ed. Resenha Tributária, $3^{\text {a }}$. tiragem, 1991.

MARTINS, Ives Gandra da Silva; BASTOS, Celso. Comentários à Constituição do Brasil. $3^{\circ}$ volume, tomo III, São Paulo: Ed. Saraiva, 1992.

MARTINS, Ives Gandra da Silva. VIDIGAL, Geraldo de Camargo. Comentários à Lei das Sociedades por Ações. Rio de Janeiro: Ed. Forense Universitária, 1999.

MATTOS, Mauro Roberto Gomes de. O limite da improbidade administrativa - $\mathrm{O}$ direito dos administrados dentro da Lei $n^{\circ}$ 8429/92. 2ª . Ed., Rio de Janeiro: Ed. América Jurídica, 2005.

MORAES, Alexandre de. Constituição do Brasil interpretada e legislação constitucional. São Paulo: Ed. Atlas, 2013.

MOSCARDO, Jerônimo. I Encontro de juristas da América Latina e do Caribe - volume IV Reflexões. Brasília: Ed. Fundação Alexandre de Gusmão, 2010.

“Plebiscito: como votarei?”. Rio de Janeiro: José Olympio Editora, 1993.

PEREIRA, Caio Mário da Silva. Responsabilidade Civil. $2^{a}$ edição. Rio de Janeiro: Ed. Forense, 1990.

RODRIGUES, Silvio. Direito Civil - Responsabilidade Civil. Volume 4, $14^{\mathrm{a}}$ ed. atualizada, São Paulo: Saraiva, 1995.

SILVA, José Afonso. Comentário contextual à Constituição, $7^{a}$. Ed., São Paulo: Malheiros Editores, 2009.

SZKLAROWSKY, Leon Fredja. Medidas provisórias. São Paulo: Revista dos Tribunais, 1991.

TRIBUNAL REGIONAL FEDERAL DA $1^{\mathrm{a}}$ REGIÃO. A Constituição na visão dos Tribunais Interpretação e julgados artigo por artigo”. São Paulo: Ed. Saraiva, 1997. 